\title{
Selective Effects of Marriage Migrations on the Population Redistribution in A Hierarchical Regional System of Japan
}

\author{
Hiroshi KAwABE* and Kao-Lee Liaw**
}

\begin{abstract}
Based on the data on 11,470 household heads and spouses in a national survey, this paper studies the selective effects of marriage migrations on five types of prefectures: (1) metropolitan core, (2) suburban, (3) regional growth pole, (4) peripheral non-kaso, and (5) peripheral kaso prefectures. The selective effects are examined in terms of five personal factors: sex, nativity, education, period of marriage, and sibling status.

High Lights. Metropolitan core type was a minor net loser of male migrants and a major net gainer of female migrants. Primary and onward migrations were much more important than return migrations so that marriage migrations increased the non-native's share of the population of every type of prefectures. Marriage migrations resulted in further deterioration of the quality of human capital in peripheral prefectures. The transition from high to moderate economic growth in the early 1970's was accompanied by sharp reversals in the net transfers of marriage migrants in metropolitan cores and regional growth poles in opposite directions. The net migration patterns of surplus and essential siblings had the same direction, although the former was more influential than the latter.
\end{abstract}

Key words: marriage migration, personal factor, net gainer, net loser, quality of human capital.

\section{INTRODUCTION}

Urban congestion, rural depopulation, and the shifting turmoil in ethnic enclaves are problems of population distribution and its changes that command the attentions of not only geographers but also other social scientists, planners, political leaders, and concerned citizens in different countries. The changes in population distribution usually depends more on the migration process than on the spatial variations in the birth and death processes (Liaw, 1992). Furthermore, since the net transfers of migrants among regions tend to be much greater for young adults (i.e. those who have high reproductive potential and very low mortality) than for people in other age groups, a region with a high net migration rate also tends to have a high crude birth rate and a low crude death rate so that the redistributional effect of net migration tends to be further amplified by the birth and death processes (KAwABE, 1991). Thus, migration is in general the most crucial process that determines the relative population growth in different areas or regions of a country.

What are the basic characteristics of the migration process? What are its major causal factors? What are its important effects? As we continued to answer such questions in our research, we became increasingly convinced that the migration process is highly selective with respect to certain personal factors and can not be easily understood without separating the total population into a set of more homogeneous subpopulations and examining their distinctive behaviors. We also became convinced that migration propensities are strongly enhanced by certain life-cycle events such as entries into postsecondary education, labor force, and marriage. Thus, the likelihood of making significant contributions to migration research could be enhanced by analyzing a high-quality micro data set that is rich in the information on

\footnotetext{
* Senshu University. Tama-ku, Kawasaki-shi, Kanagawa. Japan

** Dept. of Geography, McMaster University. Hamilton, Ontario L85s 4kl. Canada
} 
personal attributes and life-cycle events. It is fortunate that such a data set was made available to us by the Institute of Population Problems (IPP), the Ministry of Health and Welfare of Japan. The IPP data set was based on the 1986 national survey on migration histories and migration reasons (IPP, 1988).

Based on the IPP data set, we started a longterm joint research project. We began by focusing on the explanatory factors and variables on the interprefectural migrations at the life-cycle stage of marriage (KAWABE and LiAw, 1992). We now shift our attention to the redistributional effects of marriage migrations on a stratified regional system of Japan. Our objectives are to assess the overall redistributional effects of the migrations at marriage and to study how these effects varied with certain personal factors (sex, nativity, education, period of marriage, and sibling status).

\section{SPECIFICATION OF THE FIVE TYPES OF REGIONS}

Although the IPP survey allows in principle a detailed study of migrations at the level of the 47 prefectures, the observed volumes of net migrations at marriage in many prefectures were too small to allow reliable inferences. In this paper, we aggregate the prefectures into five types of regions according to the hierarchical structure of the regional system. At the top of the hierarchy, the prefectures in the three largest metropolitan areas are grouped into two types: (1) metropolitan core type, including Tokyo, Osaka and Aichi; and (2) suburban type, including Saitama, Chiba, Kanagawa, Kyoto, Hyogo, Nara, Shiga, Gifu and Mie. At the middle level of the hierarchy, three regional metropolitan prefectures (Miyagi in Tohoku Region, Hiroshima in Chugoku Region, and Fukuoka in Kyushu Region) are grouped into (3) regional growth pole type.

The remaining prefectures at the lower level of the hierarchy are called peripheral prefectures for convenience. These peripheral prefectures contain most of the municipalities that are defined by the government as "kaso" (too thin) areas which have suffered the consequences of prolonged depopulation due to net outmigrations, including the smallness of the local tax base to support the local infrastructure and basic public services. We assign a prefecture to (5) kaso type, if it satisfies the following two conditions. First, the share of its population by kaso municipalities in 1990 was higher than the national value (6 percent). Second, its index of financial potential in 1985 was lower than the average of the 47 prefectures $(0.496)$. Note that the share of prefectural population by kaso municipalities ranged between a minimum of zero (Kanagawa) and a maximum of 36.5 percent (Kagoshima), whereas the index of financial potential ranged between a minimum of 0.248 (Shimane) and a maximum of 1.208 (Tokyo). It turns out that there are 24 kaso prefectures. Finally, the remaining eight peripheral prefectures are assigned to (4) non-kaso type (Table 1).

\section{DEFINITION OF MIGRATION MEASURES}

The individuals used for this study were the household heads and spouses in the 7,825 useable household records in the IPP survey. The total number of individuals is 11,470 persons, with 5,654 (49.3\%) being male and 5,816 (50.7\%) being female. These individuals are grouped into subpopulations according to each of the selected personal factors. For each personal factor, the individuals with a missing value are deleted from the sample. The sum of all subpopulations, defined for a personal factor, is called the total population. Since different factors have different numbers of missing values, the number of individuals in the total population varies from one factor to another.1)

Let $P[g, t]$ be the size of the subpopulation " $g$ " resided in the prefectures of type " $t$ " immediately before marriage. Also let $V[g, t]$ be the corresponding net migration volume at marriage. Our basic measure of migration is the net migration rate $r[g, t]$ defined as

$$
r[g, t]=V[g, t] / P[g, t] * 100 \%
$$

The net migration rate of the total population of the prefectures of type " $t$ " is

$$
r[t]=V[t] / P[t] * 100 \%
$$


Table 1. Classification of prefectures into 'kaso' and other types, based on financial potential and kaso municipalities' share of prefectural population.

\begin{tabular}{|c|c|c|c|c|c|c|}
\hline \multirow[b]{2}{*}{ Prefecture } & \multirow{2}{*}{$\begin{array}{c}\text { Proportion of } \\
\text { population } \\
\text { shared by 'kaso' } \\
\text { municipalities } \\
\text { in } 1990(\%)\end{array}$} & \multirow{2}{*}{$\begin{array}{l}\text { Index of } \\
\text { financial } \\
\text { potential } \\
\text { in } 1985\end{array}$} & \multicolumn{2}{|c|}{ Deviations from Japan } & \multirow[b]{2}{*}{$\begin{array}{l}\text { Classified } \\
\text { type of } \\
\text { prefecture }\end{array}$} & \multirow[b]{2}{*}{ Prefecture } \\
\hline & & & $\begin{array}{l}\text { Kaso munici- } \\
\text { palities' share } \\
\text { of population }\end{array}$ & $\begin{array}{l}\text { Index of } \\
\text { financial } \\
\text { potential }\end{array}$ & & \\
\hline HOKKAIDO & 15.4 & 0.432 & 9.4 & -0.064 & KASO & HOKKAIDO \\
\hline AOMORI & 6.7 & 0.274 & 0.7 & -0.222 & KASO & AOMORI \\
\hline IWATE & 15.6 & 0.278 & 9.6 & -0.218 & KASO & IWATE \\
\hline MIYAGI & 7.5 & 0.525 & 1.5 & 0.029 & R.G.POLE & MIYAGI \\
\hline AKITA & 26.4 & 0.281 & 20.4 & -0.215 & KASO & AKITA \\
\hline YAMAGATA & 14.6 & 0.301 & 8.6 & -0.195 & KASO & YAMAGATA \\
\hline FUKUSHIMA & 9.5 & 0.476 & 3.5 & -0.020 & $K A S O$ & FUKUSHIMA \\
\hline IBARAKI & 2.9 & 0.583 & -3.1 & 0.087 & NON-KASO & IBARAKI \\
\hline TOCHIGI & 2.1 & 0.589 & -3.9 & 0.093 & NON-KASO & TOCHIGI \\
\hline GUMMA & 3.7 & 0.616 & -2.3 & 0.120 & NON-KASO & GUMMA \\
\hline SAITAMA & 0.2 & 0.709 & -5.8 & 0.213 & SUBURB & SAITAMA \\
\hline CHIBA & 0.5 & 0.653 & -5.5 & 0.157 & SUBURB & CHIBA \\
\hline TOKYO & 0.1 & 1.208 & -5.9 & 0.712 & MET.CORE & TOKYO \\
\hline KANAGAWA & 0.0 & 1.010 & -6.0 & 0.514 & SUBURB & KANAGAWA \\
\hline NIIGATA & 11.9 & 0.394 & 5.9 & -0.102 & $K A S O$ & NIIGATA \\
\hline TOYAMA & 0.7 & 0.440 & -5.3 & -0.056 & NON-KASO & TOYAMA \\
\hline ISHIKAWA & 8.3 & 0.460 & 2.3 & -0.036 & KASO & ISHIKAWA \\
\hline FUKUI & 3.0 & 0.430 & -3.0 & -0.066 & NON-KASO & FUKUI \\
\hline YAMANASHI & 10.4 & 0.379 & 4.4 & -0.117 & $K A S O$ & YAMANASHI \\
\hline NAGANO & 8.7 & 0.507 & 2.7 & 0.011 & NON-KASO & NAGANO \\
\hline GIFU & 4.6 & 0.492 & -1.4 & -0.004 & SURURB & GIFU \\
\hline SHIZUOKA & 1.7 & 0.781 & -4.3 & 0.285 & NON-KASO & SHIZUOKA \\
\hline $\mathrm{AICHI}$ & 0.8 & 1.052 & -5.2 & 0.556 & MET.CORE & AICHI \\
\hline MIE & 4.0 & 0.475 & -2.0 & -0.021 & SUBURB & MIE \\
\hline SHIGA & 0.6 & 0.602 & -5.4 & 0.106 & SUBURB & SHIGA \\
\hline KYOTO & 2.7 & 0.670 & -3.3 & 0.174 & SUBURB & KYOTO \\
\hline OSAKA & 0.0 & 0.991 & -6.0 & 0.495 & MET.CORE & OSAKA \\
\hline HYOGO & 2.5 & 0.679 & -3.5 & 0.183 & SUBURB & HYOGO \\
\hline NARA & 4.4 & 0.447 & -1.6 & -0.049 & SUBURB & NARA \\
\hline WAKAYAMA & 6.4 & 0.382 & 0.4 & -0.114 & KASO & WAKAYAMA \\
\hline TOTTORI & 11.0 & 0.273 & 5.0 & -0.223 & KASO & TOTTORI \\
\hline SHIMANE & 24.7 & 0.248 & 18.7 & -0.248 & KASO & SHIMANE \\
\hline OKAYAMA & 11.1 & 0.469 & 5.1 & -0.027 & $K A S O$ & OKAYAMA \\
\hline HIROSHIMA & 9.3 & 0.604 & 3.3 & 0.108 & R.G.POLE & HIROSHIMA \\
\hline YAMAGUCHI & 10.1 & 0.445 & 4.1 & -0.051 & $K A S O$ & YAMAGUCHI \\
\hline TOKUSHIMA & 15.9 & 0.292 & 9.9 & -0.204 & KASO & TOKUSHIMA \\
\hline KAGAWA & 2.1 & 0.457 & -3.9 & -0.039 & NON-KASO & KAGAWA \\
\hline EHIME & 16.5 & 0.399 & 10.5 & -0.097 & $K A S O$ & EHIME \\
\hline $\mathrm{KOCHI}$ & 20.2 & 0.250 & 14.2 & -0.246 & KASO & KOCHI \\
\hline FUKUOKA & 6.8 & 0.578 & 0.8 & 0.082 & R.G.POLE & FUKUOKA \\
\hline SAGA & 13.3 & 0.306 & 7.3 & -0.190 & $K A S O$ & SAGA \\
\hline NAGASAKI & 17.3 & 0.308 & 11.3 & -0.188 & KASO & NAGASAKI \\
\hline KUMAMOTO & 21.7 & 0.350 & 15.7 & -0.146 & KASO & KUMAMOTO \\
\hline OITA & 23.0 & 0.328 & 17.0 & -0.168 & KASO & OITA \\
\hline MIYAZAKI & 15.7 & 0.291 & 9.7 & -0.205 & KASO & MIYAZAKI \\
\hline KAGOSHIMA & 36.5 & 0.307 & 30.5 & -0.189 & KASO & KAGOSHIMA \\
\hline OKINAWA & 6.6 & 0.272 & 0.6 & -0.224 & $K A S O$ & OKINAWA \\
\hline MIN & 0.0 & 0.248 & -6.0 & -0.248 & & MIN \\
\hline MAX & 36.5 & 1.208 & 30.5 & 0.712 & & MAX \\
\hline MEAN & 9.3 & 0.496 & 3.3 & -0.000 & & MEAN \\
\hline JAPAN & 6.0 & 0.496 & & & & JAPAN \\
\hline
\end{tabular}

Sources: National Land Agency (1990), p. 211, and Statistics Bureau (1988), p. 33 
Table 2. The levels and efficiencies of marriage migrations: by sex, based on a sample of 11,470 household heads and spouses.

\begin{tabular}{lrrrrrr}
\hline \hline Type of Prefectures & Male & Female & Both-sex & Male & Female & Both-sex \\
\hline & \multicolumn{3}{c}{ Inmigration Rate (\%) } & \multicolumn{2}{c}{ Outmigration Rate (\%) } \\
Metro. Core & 8.7 & 32.4 & 19.9 & 10.0 & 20.7 & 15.1 \\
Suburban & 10.7 & 31.9 & 21.0 & 6.9 & 18.8 & 12.7 \\
R. Growth Pole & 7.2 & 19.1 & 13.5 & 4.9 & 25.9 & 15.9 \\
Non- $k$ aso & 2.9 & 9.3 & 6.4 & 4.5 & 20.4 & 13.0 \\
Kaso & 2.2 & 7.3 & 4.9 & 3.7 & 16.3 & 10.3 \\
JAPAN & 6.2 & 19.1 & 12.7 & 6.2 & 19.1 & 12.7 \\
& Gross Migration Rate (\%) & Migration Efficiency (\%) \\
Metro. Core & 18.7 & 53.1 & 35.0 & -7.2 & 22.1 & 13.9 \\
Suburban & 17.6 & 50.7 & 33.7 & 21.6 & 25.8 & 24.6 \\
R. Growth Pole & 12.1 & 45.0 & 29.4 & 19.1 & -15.0 & -8.3 \\
Non- $k a s o$ & 7.4 & 29.7 & 19.4 & -20.8 & -37.1 & -34.2 \\
Kaso & 5.8 & 23.6 & 15.2 & -25.9 & -38.4 & -36.1 \\
JAPAN & 12.3 & 38.1 & 25.4 & & & \\
\hline
\end{tabular}

Source: micro file from the Institute of Population Problems.

Notes: Metro. Core: Tokyo, Osaka and Aichi.

Suburban: Saitama, Chiba, Kanagawa, Kyoto, Hyogo, Nara, Shiga, Gifu and Mie.

R. Growth Pole: Miyagi, Hiroshima and Fukuoka.

Non-kaso: Ibaraki, Tochigi, Gumma, Toyama, Fukui, Nagano, Shizuoka and Kagawa.

Kaso: The remaining 24 prefectures.

where $V[t]$ and $P[t]$ are respectively the sums of $V[g, t]$ and $P[g, t]$ across all subpopulations.

When the subpopulations defined by a personal factor are very different in size, we also find it useful to measure the redistributional effect of the migrations of a given subpopulation " $g$ " by the general net migration rate:

$$
R[g, t]=V[g, t] / P[t] * 100 \%
$$

To see whether a large net migration rate of a given type of prefectures was due to its high level of interactiveness or the strong lack of symmetry between its in- and outflows, we also examine the gross migration rate and the migration efficiency. For each subpopulation in a given type of prefectures, the gross migration rate is the sum of its in- and outmigration rates and represents its interactiveness with the rest of the system, whereas the migration efficiency is its net migration rate divided by the corresponding gross migration rate and represents the asymmetry of its in- and outflows (Table 2).

\section{THE OBSERVED EFFECTS}

Ignoring the selectivity with respect to personal attributes at the outset, we found the following (Table 3). First, the general pattern of the effects of marriage migrations was a redis- tribution of population from the regional growth pole, non-kaso and kaso types of prefectures to the metropolitan core and suburban types of prefectures. Second, with a net migration rate of a small magnitude ( -2.4 percent), the regional growth pole type experienced the least redistributional effect. Thus, the basic redistributional pattern appeared to be simply from the non-kaso ( -6.6 percent) and kaso $(-5.5$ percent) peripheral prefectures to the suburban ( 8.3 percent) and metropolitan core (4.9 percent) prefectures. Third, it is interesting to note that the kaso prefectures did not suffer a greater rate of net loss in marriage migration than the non-kaso prefectures, although the net migration loss at the stage of labor force entry was probably higher for the kaso prefectures than for the non-kaso prefectures. Fourth, between the two gaining types, the rate of net gain was much higher in the suburban prefectures. Thus, the most salient feature was the large net gain of the suburban prefectures and the large net loss of the peripheral prefectures.

\section{The female/male contrast in net migra- tions at marriage}

The patterns of net migrations at marriage for the two sexes were somewhat similar, showing net losses in the peripheral non-kaso and 
Table 3. The selective effects of marriage migrations on different types of prefectures: by sex, based on a sample of household heads and spouses.

\begin{tabular}{|c|c|c|c|c|c|c|}
\hline Type of Prefectures & Male & Female & Both-sex & Male & Female & Both-sex \\
\hline & \multicolumn{3}{|c|}{ Net Migration Volume (person) } & \multicolumn{3}{|c|}{$\begin{array}{l}\text { Pre-marital } \\
\text { Population Size (person) }\end{array}$} \\
\hline Metro. Core & -19 & 149 & 130 & 1407 & 1268 & 2675 \\
\hline Suburban & 49 & 159 & 208 & 1288 & 1217 & 2505 \\
\hline R. Growth Pole & 9 & -29 & -20 & 388 & 429 & 817 \\
\hline Non-kaso & -11 & -91 & -102 & 716 & 824 & 1540 \\
\hline Kaso & -28 & -188 & -216 & 1855 & 2078 & 3933 \\
\hline \multirow[t]{2}{*}{ JAPAN } & & & & 5654 & 5816 & 11470 \\
\hline & \multicolumn{3}{|c|}{ Net Migration Rate (\%) } & \multicolumn{3}{|c|}{$\begin{array}{l}\text { Pre-marital } \\
\text { Population Composition (\%) }\end{array}$} \\
\hline Metro. Core & -1.4 & 11.8 & 4.9 & 52.6 & 47.4 & 100.0 \\
\hline Suburban & 3.8 & 13.1 & 8.3 & 51.4 & 48.6 & 100.0 \\
\hline R. Growth Pole & 2.3 & -6.8 & -2.4 & 47.5 & 52.5 & 100.0 \\
\hline Non-kaso & -1.5 & -11.0 & -6.6 & 46.5 & 53.5 & 100.0 \\
\hline Kaso & -1.5 & -9.0 & -5.5 & 47.2 & 52.8 & 100.0 \\
\hline \multirow[t]{2}{*}{ JAPAN } & & & & 49.3 & 50.7 & 100.0 \\
\hline & Genera & Migratic & Rate (\%) & \multicolumn{3}{|c|}{$\begin{array}{l}\text { Pre-marital } \\
\text { Population Distribution (\%) }\end{array}$} \\
\hline Metro. Core & -0.7 & 5.6 & 4.9 & 24.9 & 21.8 & 23.3 \\
\hline Suburban & 2.0 & 6.3 & 8.3 & 22.8 & 20.9 & 21.8 \\
\hline R. Growth Pole & 1.1 & -3.5 & -2.4 & 6.9 & 7.4 & 7.1 \\
\hline Non-kaso & -0.7 & -5.9 & -6.6 & 12.7 & 14.2 & 13.4 \\
\hline Kaso & -0.7 & -4.8 & -5.8 & 32.8 & 35.7 & 34.3 \\
\hline JAPAN & & & & 100.0 & 100.0 & 100.0 \\
\hline
\end{tabular}

Source: micro file from the institute of Population Problems.

kaso types and a net gain in the suburban type. In the metropolitan core and regional growth pole types of prefectures, the net migrations of the two sexes were, however, the opposite of each other. For males, the metropolitan core type turned out to be a net loser ( -1.4 percent), whereas the regional growth pole type was a net gainer (2.3 percent). For females, the metropolitan core type was a very impressive net gainer (11.8 percent), whereas the regional growth type was a clear net loser $(-6.8$ percent).

Thanks to both much higher interactiveness and greater efficiency in general, the female migrations had a much greater redistributional effect than the male migrations. Consequently, the metropolitan core type was an overall net gainer, whereas the regional growth pole type was an overall net loser.

An important function of marriage migrations is to reduce the interregional variation in the sex compositions of the regional populations. In Japan, the cumulative redistributional effects of the life-course migrations prior to marriage, particularly those at the stage of entering into colleges and universities (KAWABE, 1994), were greater net transfers of males into the three largest metropolitan areas. Immediately before marriage, the sex-ratios of metropolitan core and suburban types were 111.0 and 105.8, whereas those of the regional growth pole, non-kaso, and kaso types were $90.5,86.9$, and 89.4 , respectively. Immediately after marriage, these sex-ratios are, of course, all changed to 100 by marriage migrations. ${ }^{2)}$

The male dominance on "education migrations" and the female dominance on marriage migrations suggest that sex is an essential personal factor to control in studying the differential effects of migrations by other personal factors. Thus, in the following study of the roles of nativity, education, period of marriage, and sibling status, the migration measures will be presented with, as well as without, sexdisaggregation. 


\section{The differential effects of marriage mi- grations by nativity}

With respect to the prefecture of birth, all potential migrants who were born in Japan can be classified into natives (those who resided in the prefecture of birth immediately before marriage) and non-natives (those who resided in a prefecture other than the prefecture of birth immediately before marriage). The interprefectural migrations of the natives at marriage are called primary migrations, whereas the migrations of the non-natives at marriage can be either return migrations (those returning to the prefecture of birth) and onward migrations (those with a destination being different from the prefecture of birth). The distinction of these three kinds of migrations is important, because studies in the United States (LoNG, 1988; Rogers and Belanger, 1990) and Canada (NewBold and LiAw, 1991) have shown that their patterns differed in a systematic way. Another reason for making this distinction is that the migrants making these three kinds of migrations may have different propensities to maintain a multi-generational family in which the elderly can count on the support of their adult children.

Overall, the non-natives represented as many as 25 percent of the pre-marital population. Since the net transfers of migrants at the stages of entering into higher education institutions and labor force were towards the upper levels of the regional hierarchy, the non-natives' shares of pre-marital populations displayed a clear hierarchical pattern: 46 percent in metropolitan core prefectures, 32 percent in suburban prefectures, 25 percent in regional growth poles, and about 10 percent in the peripheral prefectures.

In the pre-marital population, a higher proportion of males ( 31 percent) than that of females (18 percent) were non-natives. This was true at every level in the regional hierarchy: 52 versus 39 percent in metropolitan core prefectures, 40 versus 24 percent in suburban prefectures, 31 versus 19 percent in regional growth poles, 14 versus 7 percent in non-kaso prefectures, and 15 versus 7 percent in kaso prefectures.
Since for a migrant the post-marital nativity status need not remain the same as the premarital nativity status, the choice of the subpopulation as the denominator for computing the net migration rate is not a clear-cut matter. In this paper, we use the pre-marital native subpopulation as the denominator for computing primary net migration rate, and the premarital non-native subpopulation as the denominator for computing both return and onward net migration rates.

It is shown in the literature that the American interstate and the Canadian interprovincial migrations share the following three common properties (LoNG, 1988; Newbold and Liaw, 1991). First, the overall population redistribution is mainly determined by primary migrations. Second, the directions of return migrations tend to be opposite to those of primary migrations so that the redistributional effect of primary migrations is partly cancelled out by return migrations. Third, onward migrations tend to be similar to primary migrations in direction and hence reenforce the redistributional effect of primary migrations. We found in Table 4 that the first two properties were largely evident in the marriage migrations in Japan - more so for females than for males. However, for both males and females, the third property was contradicted to some extent: (1) the metropolitan core prefectures which were a main net gainer of primary migrants turned out to be a main loser of onward migrants, and (2) the peripheral non-kaso and kaso prefectures which were main losers of primary migrants turned out to be moderate gainers of onward migrants. Actually, for females, the effects of onward migrations were somewhat similar to those of return migrations: net losses in the metropolitan core and regional growth pole prefectures on the one hand and net gains in the peripheral prefectures on the other. For both sexes, the kaso prefectures benefitted from U-turn migrations, although both effects were dwarfed by the large net losses of female and male primary migrants.

An important difference between return migrations on the one hand and primary and onward migrations on the other was that the former incurred a small net loss and the latter 


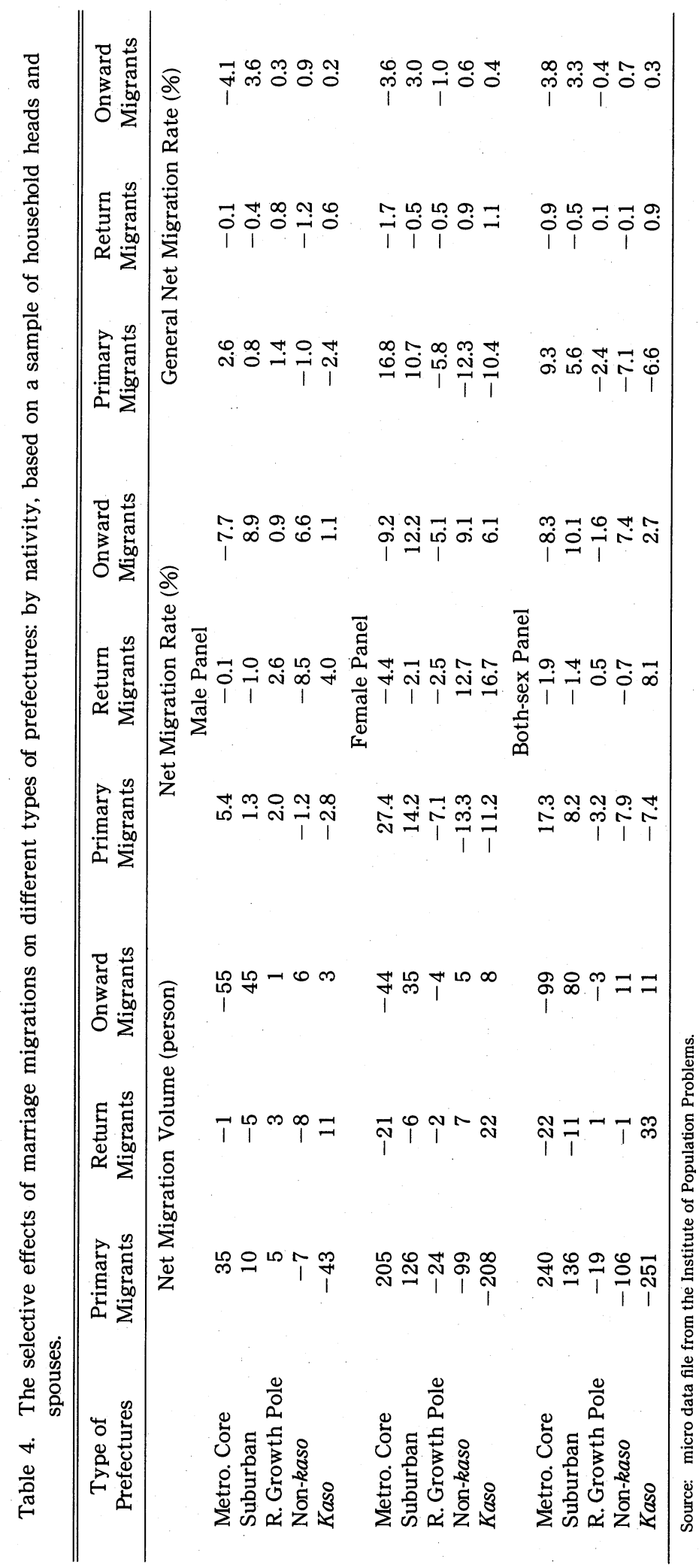


contributed large net gains to the suburban prefectures. It is worth noting that the very large overall net gain of the suburban prefectures resulted from the reenforcement of primary net migration by onward net migration. Thus, the third property mentioned above got a clear support in the case of suburban prefectures.

The general net migration rates in Table 4 show that the redistributional effects of primary and onward migrations were greater than those of return migrations. Since both primary and onward migrants ended up being nonnatives, the migrations at the stage of marriage continued the trend of increasing the non-natives' share of the total population: by as much as 8 percentage points (from 25 percent of the pre-marital population to 33 percent of the post-marital population). The continuation of this trend was strong at every level of the regional hierarchy: 7 points in the metropolitan core prefectures, 13 points in suburban prefectures, 9 points in regional growth poles, and 5 points in both non-kaso and kaso prefectures.

Since the net transfers of marriage migrants away from the prefectures of birth were much stronger for females than for males, the non-natives' shares of the post-marital regional populations became nearly identical between the two sexes. This was true for each of the five types of prefectures.

Although the marriage migrations caused the greatest increase of the non-natives' share of the population in the suburban prefectures, the non-natives' share of the post-marital population was still clearly the highest in the metropolitan core prefectures. The hierarchical pattern of this share remained very clear after marriage: 53 percent in metropolitan core prefectures, 45 percent in suburban prefectures, 34 percent in regional growth poles, and about 15 percent in peripheral prefectures.

\section{The differential effects of marriage mi- grations by education}

A main concern about the migration selectivity with respect to the level of education is the possibility for the economically less well-off peripheral regions to suffer a higher rate of net loss in the better educated subpopulations. This so-called "brain-drain" phenomenon reduces the quality of the human capital and can undoubtedly weaken the economic vitality of the less well-off regions.

We specify three subpopulations by the level of completed education: (1) the least educated (primary and junior high school graduates), (2) the well educated (high school graduates), and (3) the best educated (college and university graduates).

The brain-drain phenomenon was quite serious at the stage when the more successful high school graduates entered into colleges and universities which were strongly concentrated in the metropolitan cores and the regional growth poles. Consequently, we found in the premarital population that the population share by the best educated group was higher in the metropolitan cores (27 percent), regional growth poles (25 percent) and suburban prefectures (21 percent) than in the non-kaso and kaso prefectures (13 and 16 percent). Although there were fewer females (17 percent) than males ( 24 percent) belonging to the best educated subpopulation, this contrast held true for not only males but also females.

How did marriage migrations affect the quality of human capital of different types of regions? For the males in metropolitan core prefectures, both the best educated and the well educated subpopulations experienced net losses in marriage migrations, whereas the least educated subpopulation continued to experience a net gain (Table 5). However, the prefectures that experienced net gains of the best educated and the well educated migrants were those of the suburban and regional growth pole types rather than the peripheral non-kaso and kaso prefectures. Consequently, the migrations of males at marriage improved the quality of the human capital of the suburban areas of the three largest metropolitan areas and the regional growth poles at the expense of both metropolitan core and peripheral prefectures. However, the net transfers of male migrants were in general not large.

The net transfer of female migrants at marriage from peripheral and regional growth pole prefectures to metropolitan core and suburban prefectures happened at all three levels of edu- 
Selective Effects of Marriage Migration

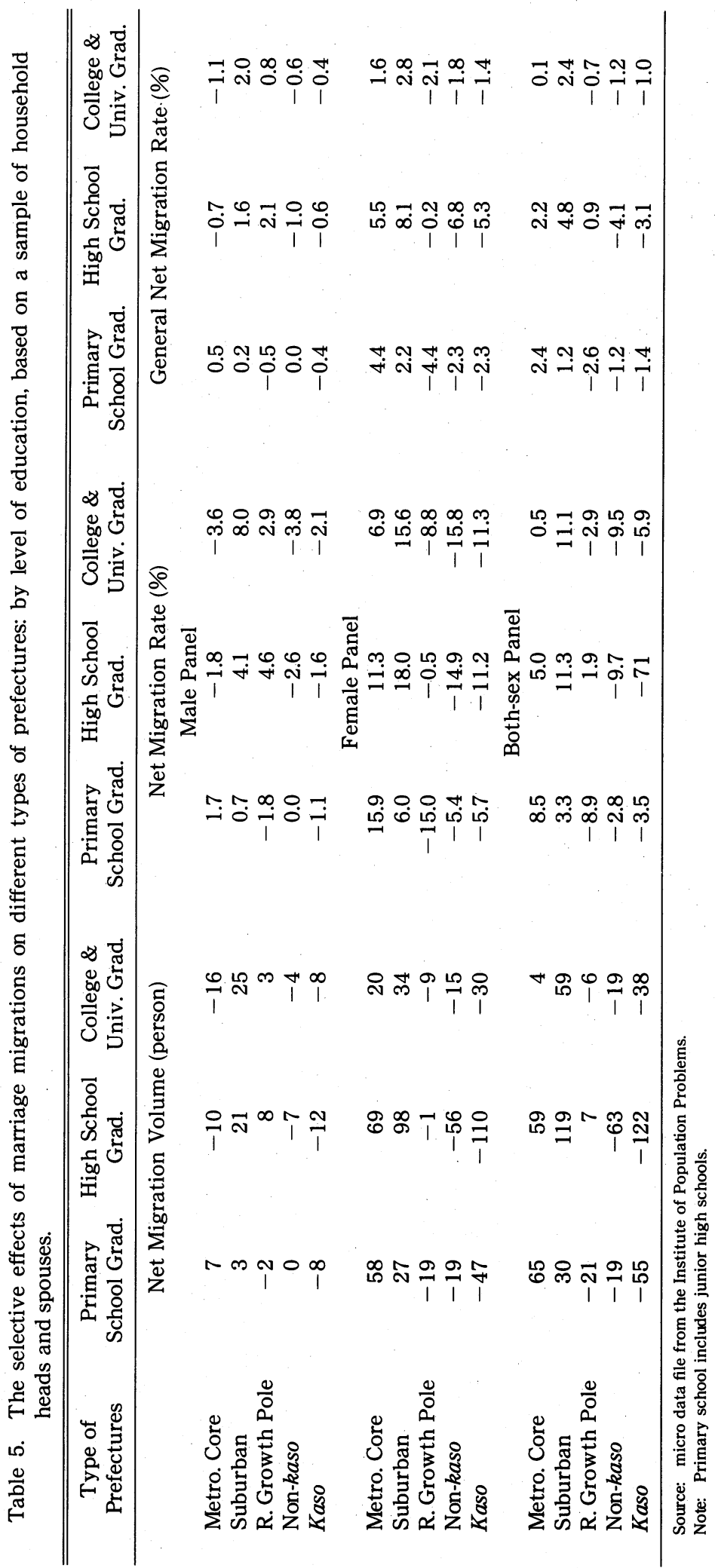


cation. For metropolitan core prefectures, the gain of the best educated females was smaller than the gain of the least educated females, resulting in a decrease of the quality of their human capital. For suburban and regional growth pole prefectures, the female marriage migrations resulted in an increased share of the well-educated and a decreased share of the least educated. For the peripheral non-kaso and kaso prefectures, the female marriage migrations resulted in a continuation of the deterioration of the human capital.

Overall, the effects of marriage migration were (1) a moderate reduction in the best educated subpopulation's share of the metropolitan core population (from 27.4 to 26.3 percent), (2) moderate increases in the shares of the suburban population by the well educated subpopulation (from 42.3 to 43.4 percent) and the best educated group (from 21.2 to 21.7 percent), (3) a shift in the composition of the population of regional growth poles from the least educated $(-1.9$ percent) to the well educated subpopulation ( +2.0 percent), and (4) a further increase in the least educated subpopulation's shares of the populations of non-kaso $(+1.8$ percent) and kaso (+0.8 percent) prefectures.

\section{The differential effects of marriage mi- grations by period of marriage}

Most of the findings about the temporal patterns of internal migration in Japan was obtained from the analysis of the matrices of annual interprefectural migrations, compiled from the system of household registration since 1954. Some of the main findings are (1) that the period of rapid economic growth was characterized by not only a large net transfer of migrants from a large number of peripheral prefectures to a few metropolitan areas but also a large scale suburbanization, and (2) that the period of moderate economic growth following the first oil crisis in 1973 was characterized by a sharp reduction or even reversal of the net gains of migrants by the three largest metropolitan areas, with the reduction being mostly limited to the core prefectures and the gains being mostly in the regional growth poles. It would be interesting to see if marriage migrations also experienced these temporal patterns.
Due to the limited number of migrants, we refrain from specifying more than the following four period of marriage: (1) the early period (pre-1946), (2) the reconstruction period (19461960), (3) the period of rapid economic growth (1961-1973), (4) the period of moderate economic growth (1974-1986). Since the survey did not ask the age at marriage, we estimated the time of marriage from the year of birth, with the assumption that the age at marriage was 27 for males and 24 for females.

The net migration transfers in the first three periods showed a common pattern, with the metropolitan cores and suburban prefectures being the gainers and the regional growth poles and peripheral non kaso and kaso prefectures being the losers (Table 6). There were also several evolving trends through these three periods: a sharp decline in the positive net migration rate of the metropolitan cores (from 14.0 percent in the early period to 7.5 percent in the period of rapid economic growth), a sharp increase in the positive net migration of the suburban prefectures (from only 1.7 percent in the early period to 9.3 percent in the period of rapid economic growth), and a magnification of the net migration' loss of the kaso prefectures (from -2.0 percent in the early period to -8.4 percent in the period of rapid economic growth). The figures reported here were for the two sexes combined. The main differences between the two sexes were (1) the decline in the attractiveness of the metropolitan cores was much stronger for males than for females, and (2) the worsening of the net loss of the kaso prefectures was much greater for females than for males.

The transition from rapid to moderate economic growth was indeed accompanied by a sharp reduction in the net gain of marriage migrants by the three largest metropolitan areas, with the reduction being limited to the core prefectures. The net migration rate of the core prefectures plummeted (from 7.5 to -6.6 percent), whereas the net migration rate of the suburban prefectures actually continued to increase substantially (from 9.3 to 12.9 percent). The peripheral prefectures continued to have negative net migration rates, although the net loss of the kaso prefectures was reduced markedly (from -8.4 to -4.1 percent). The regional 


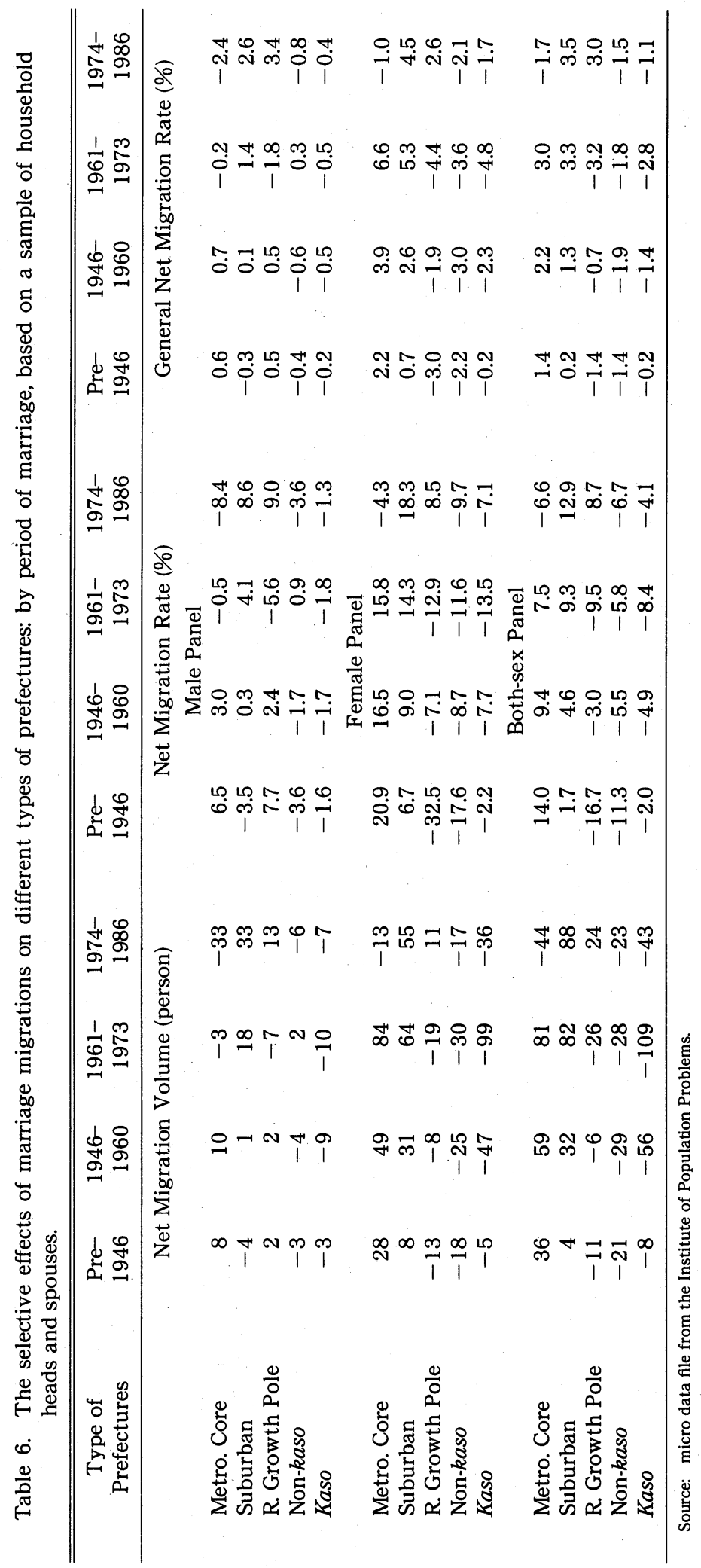


growth poles experienced the greatest increase in net migration rate (from -9.5 to 8.7 percent). Thus, the migration reversal during the transition from high to moderate economic growth was basically a sharp decline of the metropoli$\tan$ cores and a sharp rise of the regional growth poles. Since the peripheral prefectures continued to be clear net losers, the reversal in marriage migrations was not really a U-turn.

\section{The differential effects of marriage mi- grations by sibling status}

It is well known that the sharp and rapid fertility decline after the brief babyboom of the late 1940 helped make population ageing to be faster in Japan than in any other developed countries. The fertility decline was also believed to be an important factor on the mobility decline since the early 1970 s when the number of higher order siblings in the young adult populations started to decrease substantially (ITOH, 1984). This believe was based on the idea that in the traditional Japanese family, the eldest son (or the eldest daughter when male siblings were missing) was to stay with the elderly parents, whereas the higher-order siblings were obliged to leave the parental home to set up a new household. Our main interest in this section is to see if the redistributional effects of marriage migrations varied with sibling status.

In our previous work (KAwABE and LiAw 1992), we defined three subpopulations according the sibling status: (1) only children, (2) eldest sons/daughters, and (3) surplus siblings. According to our definition, the eldest daughter must be older than any other female sibling and have no male siblings. Since the net migration figures of the first two subpopulations were relatively small in magnitude, they are now merged into the subpopulation of essential siblings.

We found that sibling status did not affect the direction of the net redistribution by marriage migrations (Table 7). For males, both essential and surplus siblings displayed the same basic pattern: net losses in metropolitan core as well as peripheral prefectures and net gains in suburban and regional growth pole prefectures, although the net loss of migrants in the kaso prefectures was weaker for the essential siblings than for the surplus siblings. For females, the essential and surplus siblings shared anoth-

Table 7. The selective effects of marriage migrations on different types of prefectures: by sibling status, based on a sample of household heads and spouses.

\begin{tabular}{|c|c|c|c|c|c|c|}
\hline $\begin{array}{c}\text { Type of } \\
\text { Prefectures }\end{array}$ & $\begin{array}{l}\text { Essential } \\
\text { Children } \\
\end{array}$ & $\begin{array}{l}\text { Surplus } \\
\text { Children }\end{array}$ & $\begin{array}{l}\text { Essential } \\
\text { Children }\end{array}$ & $\begin{array}{c}\text { Surplus } \\
\text { Children }\end{array}$ & $\begin{array}{l}\text { Essential } \\
\text { Children } \\
\end{array}$ & $\begin{array}{r}\text { Surplus } \\
\text { Children } \\
\end{array}$ \\
\hline & \multicolumn{2}{|c|}{$\begin{array}{c}\text { Net Migration Volume } \\
\text { (person) }\end{array}$} & \multirow{2}{*}{\multicolumn{2}{|c|}{$\begin{array}{c}\text { Net Migration Rate } \\
\text { (\%) } \\
\text { Male Panel }\end{array}$}} & \multicolumn{2}{|c|}{$\begin{array}{c}\text { General Net Migration } \\
\text { Rate (\%) }\end{array}$} \\
\hline & & & & & & \\
\hline Metro. Core & -13 & -6 & -1.9 & -0.8 & -0.9 & -0.4 \\
\hline Suburban & 24 & 25 & 3.6 & 4.0 & 1.9 & 2.0 \\
\hline R. Growth Pole & 3 & 7 & 1.5 & 3.9 & 0.8 & 1.8 \\
\hline Non-kaso & -7 & -4 & -2.0 & -1.1 & -1.0 & -0.6 \\
\hline \multirow[t]{2}{*}{ Kaso } & -7 & -22 & -0.7 & -2.5 & -0.4 & -1.2 \\
\hline & \multicolumn{6}{|c|}{ Female Panel } \\
\hline Metro. Core & 15 & 136 & 9.4 & 12.4 & 1.2 & 10.8 \\
\hline Suburban & 8 & 150 & 5.3 & 14.2 & 0.7 & 12.4 \\
\hline R. Growth Pole & -9 & -20 & -17.0 & -5.3 & -2.1 & -4.7 \\
\hline Non-kaso & 0 & -92 & 0.0 & -12.3 & 0.0 & -11.2 \\
\hline \multirow[t]{2}{*}{ Kaso } & -14 & -174 & -6.4 & 9.4 & -0.7 & -8.4 \\
\hline & \multicolumn{6}{|c|}{ Both-sex Panel } \\
\hline Metro. Core & 2 & 130 & 0.2 & 7.1 & 0.1 & 4.9 \\
\hline Suburban & 32 & 175 & 4.0 & 10.4 & 1.3 & 7.0 \\
\hline R. Growth Pole & -6 & -13 & -2.4 & -2.3 & -0.7 & -1.6 \\
\hline Non-kaso & -7 & -96 & -1.6 & -8.7 & -0.5 & -6.3 \\
\hline Kaso & -21 & -196 & -1.7 & -7.2 & -0.5 & -5.0 \\
\hline
\end{tabular}


er basic pattern: substantial net gains in the metropolitan core and suburban prefectures and substantial net losses in kaso and regional growth pole prefectures.

However, the redistributional effect of marriage migrations was much stronger for surplus siblings than for essential siblings. On the gaining side, the net migration rates of these two subpopulations were 7.1 versus 0.2 percent for metropolitan cores and 10.4 versus 4.0 for suburban prefectures. On the losing side, the corresponding figures were -8.7 versus -1.6 for the non-kaso prefectures and -7.2 versus -1.7 percent for the kaso prefectures. The large difference between the two subpopulations was due to the fact that both the level and the efficiency of marriage migrations were greater for the surplus siblings than for the essential siblings.

\section{SUMMARY}

The most salient feature of the net transfer of migrants at marriage was a substantial net gain in suburban prefectures and large net losses in peripheral prefectures. Metropolitan core prefectures had a moderate gain, whereas regional growth pole prefectures had a minor loss.

Males and females shared a common pattern of net transfer of migrants at marriage: a net gain in suburban prefectures and net losses in peripheral prefectures. However, metropolitan core prefectures was a net loser of male migrants and a net gainer of female migrants, whereas the opposite was true for regional growth pole prefectures. The interactiveness and efficiency of migrations at marriage were greater for females than for males so that the net transfer of migrants was much greater for females than for males. The marriage migrations helped reduce the male dominance in the populations of the metropolitan prefectures, which was due to the greater net gain of male migrants through the life-course migrations prior to marriage.

At marriage, primary migrations resulted in net transfers of migrants from peripheral prefectures to metropolitan core and suburban prefectures, whereas return migrations resulted in net transfers mostly in the opposite direction. Onward migrations reenforced the primary mi- grations by amplifying the net gain of suburban prefectures but were more similar to return migrations by amplifying the net loss of metropolitan core prefectures and the net gain of kaso prefectures. Since the redistributional effect of return migrations was relatively weak, the trend of the expanding share of the population of each type of prefectures by non-natives through the successive stages of life cycle continued at the stage of marriage. This expansion was particularly large in suburban prefectures.

Migrations at marriage helped reduce the heavy concentration of the best educated subpopulation in metropolitan core prefectures. However, the prefectures with a clear improvement in the quality of human capital were the suburban ones. For peripheral prefectures, the marriage migrations continued to aggravate the deterioration of the quality of human capital.

The shift from high to moderate economic growth was not accompanied by a reversal of the net loss of marriage migrants by peripheral prefectures. Rather, it was accompanied by a sharp reversal of the net gain of marriage migrants by the metropolitan cores and a sharp reversal of the net loss of marriage migrants by the regional growth poles.

Finally, the net migration transfers of surplus and essential siblings had the same direction (from regional growth poles and peripheral prefectures to metropolitan cores and suburban prefectures), although the redistribution effect of marriage migrations was much greater for surplus siblings than for essential siblings.

\section{Acknowledgement}

We are grateful to (1) the supply of the migration data by the Institute of Population Problems, the Ministry of Health and Welfare, Japan, and (2) the financial support of the Social Sciences and Humanities Research Council of Canada (Award Number 41092-1423).

(Received Oct. 21, 1993)

(Accepted Apr. 4, 1994)

\section{Notes}

1) The numbers of individuals with missing value are quite small: 391 (3 percent) for nativity, 31 (0.3 percent) for education, 38 ( 0.3 percent) for 
period of marriage, and 75 ( 0.7 percent) for sibling status.

2) Our data yield a sex ratio of slightly less than 100 for the post-marriage population of every type of region, because the male spouses of the few households headed by females had relatively low tendency to respond to many questions in the survey and were hence more likely to be deleted from the sample due to missing values.

\section{References}

IPP (Institute of Population Problems). (1988): National Survey on migration in Japan, 1986: a study of its histories, determinants and consequences. Tokyo: IPP, Ministry of Health and Welfare, Japan, $195 \mathrm{p}$.

Iтон, T. (1984): Recent trends of internal migration in Japan and potential life time outmigrants. p2pThe Journal of Population Problems, No. 172, pp. 24-38. (JE)

KAWABE, H. (1991): Migration, age and reasons for migration. H. KAWABE (ed.), Internal migration in developing countries. Institute of Developing Economies, Tokyo, 3-23. (JE)

KAWABE, H. (1994): Some characteristics of internal migration of Japan: an observation of migration history. NUPRI Research Paper Series (Japanese Series), No. 2, Population Research Institute, Nihon
University, Tokyo, 55 p. (J)

KAWABE, H. and Liaw, K. L. (1992): Marriage and migration in Japan: an explanation by personal factors and ecological variables. NUPRI Research Series, No. 60, Population Research Institute, Nihon University, Tokyo, $51 \mathrm{p}$.

LIAw, K. L. (1992): Interprefectural migration and its effects on prefectural populations in Japan: an analysis based on the 1980 census. The Canadian Geographer, 36, No. 4, 320-335.

LoNG, L. (1988): Migration and residential mobility in the United States. Russell Sage Foundation, New York, $397 \mathrm{p}$.

National Land Agency. (1990): Current status of the policy on kaso areas. Marui Kobunsha, Tokyo, $307 \mathrm{p}$. (J)

Newbold, K. B. and Liaw, K. L. (1990): Characterization of primary, return, and onward interprovincial migration in canada: overall and age-specific patterns. Canadian Journal of Regional Science, 13, No. 1, 17-34.

Rogers, A. and Belanger, A. (1990): The importance of place of birth in migration and population redistribution analysis. Environment and Planning A, 22, No. 2, 193-210.

Statistics Bureau. (1988): Social indicators by prefecture. Statistics Bureau, Management and Coordination Agency, Japan, 617 p.

\title{
結婚に伴う人口移動の人口分布に及ぼす影響について
}

\author{
河邉 宏*・カオーリーリャウ**
}

11,470 の世帯主とその配偶者を対象として行われた 人口移動歴の調查データから, 結婚に伴って発生した県 間移動を性, 定住性, 教育程度, 結婚期間, 続柄の 5 属 性別に，大都市圈中核部，大都市圈周辺部，地方中核， 地方の非過疎地域, 過疎地域の 5 類型のそれぞれについ て観察して得られた結果の概略は，(1) 大都市圈中核部 では女子は流入超過, 男子は若干流出超過であるが, 結
婚に伴う移動が他地域出生者の割合を上昇させるように 作用しており，過疎地域での人的資源が将来一層枯渴す るように作用している, (2) 結婚に伴う移動では, 石油危 機以降とそれ以前とでは大都市圈中核部では流出超過か ら流入超過への変化が, また過疎地域とでは移動方向に 反対の逆転が見られる，(3) 世帯主之配偶者の続柄別の 移動方向は同じである, という点である。 